\title{
THE ROLE OF RESIDUAL CLAIMS AND SELF-ENFORCEMENT IN FRANCHISE CONTRACTING
}

\author{
Francine Lafontaine \\ Emmanuel Raynaud \\ Working Paper 8868 \\ http://www.nber.org/papers/w8868 \\ NATIONAL BUREAU OF ECONOMIC RESEARCH \\ 1050 Massachusetts Avenue \\ Cambridge, MA 02138 \\ April 2002
}

We thank two referees and David Leibsohn for their comments, and our respective institutions for their support. This paper is an updated and translated version of "Créances résiduelles et flux de rentes comme mécanismes incitatifs dans les contrats de franchise: compléments ou substituts," Revue d'économie industrielle, 2000, 92, 255-276. This paper is forthcoming in Eric Brousseau and Jean-Michel Glachant eds, The Economics of Contracts: theories and applications, Cambridge University Press, 2002. The views expressed herein are those of the authors and not necessarily those of the National Bureau of Economic Research.

(C) 2002 by Francine Lafontaine and Emmanuel Raynaud. All rights reserved. Short sections of text, not to exceed two paragraphs, may be quoted without explicit permission provided that full credit, including (C) notice, is given to the source. 
The Role of Residual Claims and Self-Enforcement in Franchise Contracting

Francine Lafontaine and Emmanuel Raynaud

NBER Working Paper No. 8868

April 2002

JEL No. L2, D2

\begin{abstract}
Much of the economic literature on franchising has been concerned with incentive issues and how these are managed in franchised contracts. Two main types of incentive mechanisms have been identified: residual claims and self enforcement. In this paper we describe these incentive mechanisms, and their use in franchise contracts. We argue that although these two types of mechanisms are usually thought of as alternative ways to align franchisee and franchisor incentives, they are in fact complementary in franchise contracts because they address different incentive problems. We explore what these incentive problems are, and then describe specifically how franchise contract terms and practices support each type of incentive mechanism. Finally, we discuss briefly, via two examples, how our analysis also applies to non-franchised systems with common marks or other reputation concerns.
\end{abstract}

Francine Lafontaine

University of Michigan Business School

701 Tappan Street

Ann Arbor, MI 48104

and NBER

laf@umich.edu
Emmanuel Raynaud

INRA SADAPT and Centre ATOM (U. of Paris I) INRA SADAPT, 16 rue Claude Bernard

75231, Paris cedex 05, France

eraynaud@inapg.inra.fr 


\section{THE ROLE OF RESIDUAL CLAIMS AND SELF-ENFORCEMENT IN FRANCHISE CONTRACTING}

\section{INTRODUCTION}

Franchising is a contractual relationship that has received a significant amount of attention in the economic literature on contracting. In large part, this is because franchising is one of the few types of contractual relationships about which significant amounts of data are available from public sources. But franchising is also, as noted by Williamson (1991), a hybrid organizational form, which lies somewhere between complete vertical integration and spot markets. Thus insights gleaned from the study of franchise contracts have allowed researchers to develop a better understanding not only of this organizational form, but also of organizational issues more generally, both within and across firms.

Much of the economic literature on franchising specifically has been concerned with incentive issues and how these are managed in these contracts. This literature has identified two main categories of incentive mechanisms relevant to the franchise relationship: residual claims and self enforcement. The former relates to the fact that franchisees get to keep their outlet's profits net of the fees they pay to their franchisors, giving them incentives to maximize those residual profits. The second relies on the presence of ongoing rent at the outlet level, rent that the franchisee forgoes if his contract is terminated. Such rent are simply the difference between the (net present value of) returns that the franchisee earns as a result of being associated with the franchised chain and the returns he could garner in his next best alternative. If the rent is positive, and franchisors can terminate franchisees, franchisees will have incentives to perform according to the standards set by the franchisor to reduce their chances of termination and protect their access to the rent. 
In this paper, we describe how these two types of incentive mechanisms work in theory and in practice in franchise contracting, and then explore the relationship between them. Our contention is that rather than being alternative approaches to aligning the incentives of contracting parties as suggested by much of the current literature, these approaches are in fact complementary. Specifically, we argue that residual claimancy rights motivate individual parties to a contract to invest greater effort as per standard agency arguments. At the same time, the existence of self-enforcement mechanisms prevent parties from engaging in individually profitable activities that can have a negative impact on the whole, or on other members of the franchise system. In fact, it is precisely the franchisee's status as a residual claimant that brings about the need to use a self-enforcement mechanism to curb his tendency to maximize his own profit at the expense of the brand or the rest of the chain. We argue that optimal contract design in this context must effectively balance the provision of high effort incentives for individuals with coordination incentives that preserve the value of group membership.

The paper is organized as follows. In the next section, we describe the theory behind the two types of incentive mechanisms mentioned above. In Section 3 we develop our main argument on the complementarity between residual claims and self enforcement in franchise contracts. Section 4 describes more specifically how, in practice, various aspects of the franchise relationship or contract clauses support the two types of incentive mechanisms discussed herein. Section 5 illustrates, via two examples, how our analysis generalizes to non-franchised networks of firms that operate under common brands or reputation concerns. Concluding remarks are found in Section 6. 


\section{Residual Claims and Ongoing Rent as InCEntive Mechanisms}

Franchising fundamentally involves franchisors granting franchisees the right to operate under their trademarks and business processes in exchange for various fees. As the intangible assets involved in this transaction remain the property of the franchisor, the granting of these rights gives rise to incentive problems and agency costs. As noted above, two main types of incentive mechanisms have been identified in the economic literature on franchise contracting as ways to mitigate these problems: the granting of residual claimancy rights, as emphasized in the principal-agent literature (see e.g. Rubin, 1978, and Mathewson and Winter, 1985) and the reliance on self enforcement, which involves the provision of a stream of ongoing rent downstream that the franchisee forgoes in the event of contract termination (see in particular Klein and Leffler, 1981, and Klein, 1995). In what follows, we discuss the theory behind the functioning of these two types of mechanisms in the context of franchising.

\section{Residual Claims in Franchise Contracting}

Franchisee-owned businesses are legally independent from the business of their franchisor. Franchisees can own one or several franchised outlets in a chain, and as owners, they have a claim on the profits generated by their outlet(s). Franchisees claim these profits net of the usual sales-based royalties and advertising fees they pay to their franchisors. As these payments normally represent 6 to $10 \%$ of revenues, franchisees obtain the bulk of every additional dollar of sales generated within their outlet(s). ${ }^{1}$ Also, since royalty and advertising fee payments are

\footnotetext{
${ }^{1}$ In Product and Trade Name franchising, franchisees do not pay these sales-based royalties. However, the markups charged by the franchisor on every unit of input can be equivalent to sales royalties under certain conditions. See Lafontaine and Slade (2001) for more on this.
} 
based on revenues and not profits, franchisees reap the full benefit from every additional dollar decrease in operating costs.

When franchisee effort is not observable, and so cannot be contracted on directly, it is optimal for the franchisor to sell the outlet to the franchisee for a fixed price (assuming that the franchisee's effort is central to production). This outright sale makes the franchisee a full residual claimant, thereby giving him incentives to put forth the optimal level of effort (see e.g. Rubin, 1978, and Mathewson and Winter, 1985). Specifically, assume that sales S depend on franchisee effort in the following way:

$$
S=a e+\varepsilon
$$

where $e$ is franchisee effort and $a$ measures the importance of the franchisee's effort in the sales generation process. $\varepsilon$ is a random variable with mean 0 and variance $\sigma^{2}$ that prevents the franchisor from inferring $e$ from observed $S$. If the cost of effort for the franchisee is $C(e)=e^{2} / 2$ and $F$ is the price at which the franchisor sells the outlet to the franchisee, the risk-neutral franchisee will want to maximize expected profits, namely

$$
\pi=a e-e^{2} / 2-F .
$$

The first-order condition for this maximization problem gives $e^{* *}=a$, which corresponds to the first-best level of effort and, thus, to the level of effort that the franchisor would have chosen if she had control over it. In that sense, selling the outlet at a fixed price to the franchisee completely resolves franchisee incentive issues. The franchisor can extract all the profits from the outlet operations by appropriately setting the price, $\mathrm{F}$, at $F=a^{2} / 2{ }^{2}$

\footnotetext{
${ }^{2}$ To simplify the algebra, we ignore issues of contract duration and discounting. This in no way affects the generality of the result that a fixed price contract resolves all incentive issues when franchisees are risk neutral. Note that $F$ could be set at any level not exceeding $a^{2} / 2$. But any $F$ below $a^{2} / 2$ means that the franchisor does not
} 
In practice, franchisees usually don't acquire outlets at a fixed price. Instead, they pay a nominal fixed fee, plus a proportion of their revenues every period over the whole duration of the contract. The typical franchise contract thus involves sharing. ${ }^{3}$ Yet, under our assumptions, sharing is counterproductive - it prevents the realization of the first-best outcome. In particular, the franchisee who must pay a portion $\alpha$ of his revenues to the franchisor (where $0<\alpha<1$ represents the sum of all revenue-based fees such as royalty rates and advertising fees), maximizes

$$
\pi=(1-\alpha) a e-e^{2} / 2-F
$$

by setting effort $e^{*}=(1-\alpha) a$. In other words, the effort level $e^{*}$ chosen by the franchisee subject to royalty payments is strictly lower than the effort level $e^{* *}$ that a franchisee would choose under a fixed-price contract, so one would not expect sharing to be used in this setting.

The principal-agent literature provides two alternative amendments to the model above to account for the use, in practice, of sharing arrangements. The first amendment, which is the most traditional, involves introducing the assumption that the franchisee is risk averse rather than risk neutral (see for example Stiglitz, 1974, for the first such model, applied to sharecropping). In this case, the franchisee no longer maximizes expected profits, but rather expected utility. Sharing in this model then becomes a means of shifting risk from risk-averse agents (franchisees) to risk-neutral principals (franchisors). The second amendment to the model relies instead on the assumption that the principal (franchisor) provides some valuable input in the production process and that her behavior, like that of the agent (franchisee), is difficult to monitor. In this model,

make as much as he could, and the franchisee does better than required by his participation constraint. We come back to this below.

${ }^{3}$ Sharing occurs also, for example, in sharecropping, licensing, film distribution, and publishing contracts. 
called a double-sided moral hazard model, sharing arises from the need to provide incentives to the franchisor as well as the franchisee (see notably Rubin, 1978; Eswaran and Kotwal, 1985; Lal, 1990; and Bhattacharyya and Lafontaine, 1995). We discuss each of these amendments in more detail in what follows.

\section{A. Franchisee Risk Aversion}

Where the franchisee is risk averse rather than risk neutral, he maximizes his expected utility from outlet profits or his certainty equivalent income. Assuming that $\varepsilon$ is normally distributed, and that the franchisee has a constant absolute risk-aversion parameter of $\rho$, his certainty-equivalent income is given by

$$
C E=E(y)-C(e)-(\rho / 2) \operatorname{Var}(y)=(1-\alpha) a e-F-e^{2} / 2-(\rho / 2)(1-\alpha)^{2} \sigma^{2},
$$

where $E(y)$ are his expected revenues. ${ }^{4}$ Taking the first derivative of $C E$ with respect to $e$ and setting that equal to zero, the solution to the franchisee's maximization problem, as before, is to choose an effort level $e^{*}=(1-\alpha) a$. The franchisor then must choose $\alpha$ to maximize total surplus taking for granted that the franchisee will provide an effort level $e^{*}=(1-\alpha) a$ (i.e. an effort level that depends on $\alpha$.). Substituting $e^{*}$ in the equation for expected total surplus (given by $a e-e^{2} / 2$ $\left.-(\rho / 2)(1-\alpha)^{2} \sigma^{2}\right)$, we have

$$
\max \left[(1-\alpha) a^{2}-(1-\alpha)^{2} a^{2} / 2-(\rho / 2)(1-\alpha)^{2} \sigma^{2}\right]
$$

$\alpha$

\footnotetext{
${ }^{4}$ See e.g. Milgrom and Roberts (1992) p. 217.
} 
The first-order condition for the franchisor's problem implies that $\alpha^{*}=\left[\rho \sigma^{2} /\left(a^{2}+\rho \sigma^{2}\right)\right]$

$>0$. In words, the "best" linear (or more precisely affine) contract from the franchisor's perspective now involves some sharing. This sharing arises as a way to balance the need to motivate franchisee effort (which makes the optimal $\alpha$ lean toward 0 ) while providing insurance

to now risk-averse agents (which makes the optimal $\alpha$ lean toward 1). Of course, while this

solution is optimal from the franchisor's perspective, it does not give rise to the first-best level of effort and output as $e^{*}=(1-\alpha) a<a=e^{* *}$.

\section{B. Franchisor Moral Hazard}

Turning to the second amendment to the model, we now assume that the franchisor as well as the franchisee provides some non-observable input that contributes to the franchised outlet production or sales process. In this case, even under risk neutrality for both franchisor and franchisee - which we now assume for simplicity - the optimal linear contract will involve sharing. ${ }^{5}$ The share parameter here trades off franchisor and franchisee incentives. To illustrate, assume that outlet sales are given by

$$
S=a e+b r+\varepsilon
$$

where $r$ is the franchisor's effort level. Assume further that the franchisor's cost of effort is given by $C(r)=r^{2} / 2$. The franchisee maximizing his profits given any $\alpha$ will again choose $e^{*}=$

\footnotetext{
${ }^{5}$ If the franchisee is risk averse while the franchisor is risk neutral, as in our previous setting, sharing will arise as an optimal response (under linearity) still. In this case, the share parameter will play the double role of providing incentives to the franchisor as well as insurance to the franchisee.
} 
$(1-\alpha) a$. The franchisor who gets a fraction $\alpha$ of outlet sales will set $r^{*}=\alpha b$. Substituting these two effort levels into the franchisor's maximization problem yields

$$
\max \left[(1-\alpha) a^{2}+\alpha b^{2}-(1-\alpha)^{2} a^{2} / 2-\alpha^{2} b^{2} / 2\right] .
$$

The first-order condition for this maximization problem gives $\alpha^{*}=b^{2} /\left(a^{2}+b^{2}\right)>0$, which once again implies sharing.

Three main testable implications arise from these two types of principal-agent models. The share parameter $\alpha$ (here the sum of royalties and sales-based advertising fees paid by franchisees to their franchisor) will be higher:

1) the lower the importance of franchisee effort, as captured by $a$ above;

2) the higher the level of risk involved $\left(\sigma^{2}\right)$ (assuming the franchisee is more risk averse than the franchisor);

3) the more important franchisor effort is, as captured by $b$ above (assuming this effort is non-observable).

The empirical literature on franchising has found support for 1) and 3), but not for 2) .

Our discussion thus far has focused on the incentives embedded in franchise contracts via residual claims. It is important to note, however, that employment contracts also can accord residual claimant status to employees. And an employee-manager whose compensation was directly tied to the profits of the outlet he manages would choose the same effort level as a franchisee as long as his contract entailed the same "level" of residual claims. ${ }^{7}$ In practice,

\footnotetext{
${ }^{6}$ See Lafontaine and Slade (2001) for a review of the empirical literature on franchise contracting. Lafontaine and Bhattacharyya (1995) discuss measurement issues related to tests of the effect of risk on royalties and extent of franchising, and propose a theoretical explanation for the observed "reverse" effects based on the idea that measured risk is a result of high-powered incentives for franchisees. See also Prendergast (2002) for more on this topic.

${ }^{7}$ See Lutz (1995) for more on this.
} 
however, franchise contracts normally entail residual claimant status for franchisees whereas the compensation of managers of company units in franchised chains usually is not tied very closely to outlet profits (see Bradach, 1997, for evidence.)

\section{Self-Enforcement}

In this section, we turn our attention to the role of hostages (Williamson, 1985), efficiency wages (Shapiro and Stiglitz, 1984; Akerlof and Yellen, 1986) and self enforcement more generally (Klein, 1980; Klein and Leffler, 1981; Klein and Saft, 1985) in franchise contracting. The common thread across all these analyses is the notion that parties to a contract can be given incentives to put forth effort by making sure that they derive a benefit from the relationship that is at risk if they do not behave as requested. The incentives embedded in a franchise contract in this context do not stem from residual claims, but rather from the combined effect of three elements: (i) an ongoing stream of rent that the franchisee earns within the relationship but forgoes if he "leaves" the franchised chain, (ii) franchisee monitoring by the franchisor, and, (iii) franchisor ability to terminate the franchise contract. Since the ease or cost of termination is largely determined by the applicable legal system, the franchisor is left with the tasks of choosing the level of ongoing rent to be left with franchisees and selecting the frequency of monitoring so as to minimize the ex post cost of enforcing the desired level of effort. ${ }^{8}$

Specifically, let $W_{t}^{l}$ represent the (expected) franchisee gain from deviating from the franchisor's requested behavior, a gain that may be the same from period to period, or vary somewhat across periods. Letting $W_{t}^{2}$ be the present value of ongoing rent that the franchisee can earn within the relationship, a franchise contract is self enforcing if and only if $W_{t}^{2}>W_{t}^{l}$ at

\footnotetext{
${ }^{8}$ For self-enforcement to work, the franchisor must be able to evaluate, ex post, whether or not the franchisee's performance is satisfactory even if the desired effort is too complex to specify in the contract.
} 
every t. In other words, for the contract to be continuously self-enforcing, the franchisee must have a minimum amount of rent to look forward to at each point in time. For that reason, given that the expected rent over the remainder of the contract decreases as the franchise gets closer to expiration, $W_{t}^{2}$ must include not only this rent, but also rent associated with future additional outlets and with the probability of contract renewal. ${ }^{9}$

In this framework, specific contract terms (described in more detail in section 4) play different roles (Klein, 1995), influencing either $W_{t}^{1}$ or $W_{t}^{2}$ :

\section{i) Contract Terms Affecting $W_{t}^{1}$ :}

Some contract terms specify certain franchisee obligations, for example the mandatory level of input purchases from the franchisor, other procurement requirements, minimum local advertising expenditures, or staffing levels. These contract terms limit $W_{t}^{l}$ as they make it easier for the franchisor to detect non-conformance and quickly intervene to limit the benefit from deviation to the franchisee. They also make it less costly for the franchisor to rely on third party or court enforcement as they provide more objective bases from which to establish non-conformance.

\section{ii) Contract Terms Affecting $W_{t}^{2}$ :}

Other contract terms serve to ensure the existence of the stream of ongoing rent whose potential loss gives incentives to the franchisee. Although Klein $(1980,1995)$ does not specify exactly how the stream of rent is created, he suggests that clauses such as exclusive territories limit intra-brand competition and thus contribute to the franchisee's

\footnotetext{
${ }^{9}$ Indeed, only high performance franchisees can expect renewal and additional outlets within the same chain. These decisions therefore entail rent that gives further incentives to franchisees. See Kaufmann and Lafontaine (1994) for more on this.
} 
profitability. ${ }^{10}$ As noted above, guarantees about future expansion opportunities and likelihood of contract renewal would further affect the level of expected rent.

Due to a combination of uncertainty, complexity and lack of perfect monitoring, all aspects of the behavior desired of franchisees cannot be specified by the franchisor in the contract a priori. Hence the franchisee always has some leeway, and $W_{t}^{1}$ is never zero. As a consequence, the contract must always give rise to positive rent $W_{t}^{2}$ if the incentive constraint above is to be continuously satisfied. At the same time, there exists a maximum amount of rent to which the franchisor can credibly commit. If the franchisor prefers franchising to company managed stores, this is presumably because vertical integration (company management) is less profitable, either due to higher costs or lower revenues or both. In other words, $\Pi_{t}^{F}-\Pi_{t}^{I}>0$, or the difference in profit between operating a unit under franchising and under company operations at any time $t$, is positive. The franchisor's promise of rent to the franchisee then is credible if the present value of the rent, $W_{t}^{2}$, is less than the discounted profit difference, at every $\mathrm{t}$, namely

$$
W_{t}^{2}<\sum_{\tau=t}^{\infty} \frac{\left(\Pi_{\tau}^{F}-\Pi_{\tau}^{I}\right)}{(1+\delta)^{\tau}}
$$

where $\delta$ is a discount rate. If this condition is continuously met, then it is in the best interest of the franchisor to pay the rent. ${ }^{11}$ Otherwise, it is more profitable for the franchisor to vertically integrate and appropriate the rent. ${ }^{12}$

\footnotetext{
${ }^{10}$ This assumes that franchisees can earn profits in the long run, i.e. that they do not operate in a perfectly competitive or monopolistically competitive market. If profits were dissipated in the long run, there could be no rent in the long run, and thus no self enforcement. In other words, Klein's analysis presumes that branding allows franchisees to differentiate their product enough that they earn positive profits in the long run (which the franchisor may or may not extract fully up-front - we come back to the issue of rent extraction below).

${ }^{11}$ See Shelton (1967) for evidence that costs are lower under franchisee than company management. As for the revenue side, in a private conversation, a franchisor mentioned how, if he had hired one of his franchisee, he would never have paid him a salary that amounted to anything close to what this franchisee was earning in profits in his
} 
Empirically, Kaufmann and Lafontaine (1994) have shown, through a detailed analysis of the economics of McDonald's restaurants in the U.S., that there is indeed rent left downstream in that chain. Following a similar methodology, Michael and Moore (1995) confirmed the existence of rent in a number of other franchised chains. Moreover, Brickley, Dark and Weisbach (1991) have shown that the proportion of corporate units in franchised chains is higher in U.S. states that restrict the termination of contracts compared to other states (see also Beales and Muris, 1995). Finally, Brickley (2002) shows that franchisors headquartered in states with restrictive non-renewal or termination rules - and whose outlets are mostly in such states as a result - charge higher fees, in total, than their counterparts established in non-restrictive states. These results suggest that the cost of termination indeed affects franchisors' decisions to franchise or vertically integrate outlets or the terms of their contracts, thereby lending support to the idea that franchisors rely on rent and termination in their dealings with their franchisees.

Finally, it is important to note that the use of rent and self-enforcement as an incentive mechanism is in no way limited to the franchise context. In fact, the huge literature on "efficiency wages" in labor economics shows that the provision of "rent" and its potential loss are used to motivate employees within firms just as they can be used to motivate franchisees. This suggests that a franchisor could well use efficiency wages to motivate her store managers and, in doing so, eliminate the need to give store managers residual claims or use franchisees.

outlets. But the franchisor also admitted that he never considered buying back the outlets as he did not expect that he could have made as much money with the units under corporate ownership as he was making in royalties given this franchisee's management skills and effort (and the franchisor did not expect the franchisee would have put in anything close to the same effort if he had been an employee).

${ }^{12}$ See Williams (1996) and Brickley (2001) for an argument that as the market changes, the amount of rent may change in a way that makes integration the preferred option. The franchisor who then terminates or does not renew a franchise contract can be thought of as exercising the equivalent of a "call option." 


\section{SUBSTITUTES OR COMPLEMENTS?}

In this section, we consider why both residual claims and self enforcement coexist at McDonald's and in other franchise systems. This coexistence is puzzling given that the agency and the self-enforcement literature each suggest that its incentive mechanism is sufficient, in itself, to resolve incentive issues.

Specifically, the self-enforcement literature, and Klein in particular, never considers the use of residual claims as an incentive mechanism. In this literature, the combination of a stream of rent, periodic monitoring and the termination option are sufficient to achieve the desired outcome. There is therefore no role for residual claims in the analysis.

Similarly, in the literature that emphasizes residual claims as a source of incentives, rent does not enter into play at all. If, ex ante, the franchisor has designed an optimal (linear) contract, i.e. a contract that satisfies the franchisee's incentive constraint as well as his participation constraint, the franchisee earns no rent. In some of these models franchisees do earn rent, but these arise from the need to use the right share parameter, $\alpha$, while also satisfying some liquidity or selection constraint (see Mathewson and Winter, 1985). The rent serves no direct incentive purpose in these models. Furthermore, as the contract is designed with the franchisee's optimal reaction in mind, the franchisee has no reason to deviate ex post, and the final outcome is exactly what the franchisor expects it to be.

Why, given this, do we see residual claims and self enforcement being used together in franchise contracts? We believe that this coexistence arises because residual claims give franchisees the incentive to put forth effort and not shirk, while ongoing rent give franchisees the incentive to maintain the value of the brand by acting in the chain's collective interests. In fact, our premise is that it is precisely franchisees' residual claimant status that generates the need to 
use a self-enforcement mechanism that curbs the tendency of franchisees to maximize their own profit at the expense of the overall chain. In short, we contend that the two mechanisms work in tandem and complement one another rather than being alternatives for one another.

But what are those behaviors that franchisees might engage in to increase their profits at the expense of the chain? Franchisee free riding on the value of the brand is one form of franchisee "misbehavior" that has been discussed frequently in the franchising literature. The issue, in essence, is one of externality: the franchisee bears the full cost of maintaining high quality in his outlet, but the benefit of his behavior accrues not only to him in the form of high outlet sales, but also to all others in the chain as well as to the franchisor as high quality in each outlet leads to higher sales overall in the chain. In that sense, the quality level that maximizes the franchisee's profits is always lower than that desired by the franchisor (see Brickley, Dark and Weisbach, 1991, and Blair and Kaserman, 1994). Similarly, the prices that maximize a franchisee's profits are higher than those that maximize chain profits. This again stems at least partly from the fact that the franchisee does not appropriate the positive effect of his low prices on sales at other outlets in the chain (see e.g. Barron and Umbeck, 1984; Shepard, 1993, and Lafontaine, 2001, for more on this). Finally, franchisees can refuse to implement new production processes or to sell new products that they don't expect will be profitable in their particular market even if they are expected to be worthwhile for the chain, or they may choose to modify processes or product offerings to better fit their particular market (see for instance Kaufmann, 1987, and Lewin-Solomon, 1998). ${ }^{13}$

\footnotetext{
${ }^{13}$ Brickley \& Dark (1987) also point out that franchisees tend to under invest in their outlets as they must assume most of the investment risk. While this effect is due to risk aversion rather than the presence of an externality, it again implies that the franchisee may not act in the best interest of the chain as a whole.
} 
All of these franchisee profit maximization strategies correspond to "misbehaviors" from the chain's perspective. To understand why, one need merely reflect on the franchised chain's "raison d'être": to offer consumers a predictable, homogeneous product across a large number of geographically dispersed establishments. In fact, homogeneity is the goal not only for product offerings, but also for building design, ambiance, service and price as this is at the heart of sustaining the value of the franchised chain brand. If a particular franchisee offers lower service or less quality, consumers may well infer that overall chain quality is declining, and choose not to frequent any of the chains' establishments in the future. Similarly, a franchisee's effort to satisfy his local customers via special product offerings may affect the franchise chain negatively if consumers become confused about what to expect, or are disappointed when other outlets do not carry their favorite product. In short, franchisees' efforts towards individual profit maximization can adversely affect the franchisor and other franchisees by eroding the value of the brand on which all parties in the chain depend, and thus adversely impacting the value of group membership itself.

Our argument so far, however, raises an important issue: if the franchisee's residual claimant status leads him or her to behave in ways that are inconsistent with what is optimal for the chain, thereby requiring the use of supplemental incentive mechanisms, why don't franchisors simply use self-enforcement mechanisms without relying on residual claims at all to motivate franchisees? After all, the self-enforcement literature implies that one can obtain the desired behavior simply with an appropriate combination of ongoing rent, monitoring and termination.

We suggest that the answer to this question lies in the different types of tasks required of franchisees. Specifically, some of the activities that franchisees engage in, such as all those 
related to day-to-day outlet operations, are very costly to monitor, especially for geographically dispersed outlets. Moreover, individual outlet sales and profits are fairly highly correlated to franchisee effort for these types of tasks. Residual claims are a particularly appropriate incentive tool in such contexts, i.e. when output measures (here sales and profits) are good proxies for effort and effort is difficult to monitor (see Lafontaine and Slade 1996 for more on this). ${ }^{14}$ By contrast, a franchisee's decision to implement or not new production procedures or new product offerings, or to participate in various system-level activities, and more generally to comply with explicit contract clauses such as those that govern supplier choices and minimum advertising levels, are all fairly easy (low cost) to monitor. The correlation between an individual outlet's sales and compliance by the franchisee with all these policies, however, need not be high at all. If sales and or profits do not provide a good measure of such effort, residual claims will not give franchisees the right incentives to implement them. Franchisors will therefore do better using a self-enforcement mechanism to get the franchisee to participate in these.

\section{SPECIFIC CONTRACT TERMS AND IMPLEMENTATION}

So far, we have focused our discussion on the role of residual claims and self enforcement in aligning franchisee and franchisor incentives without providing much detail as to how these mechanisms are implemented or supported via specific contract terms. In this section, we briefly describe how specific franchise contract terms serve to implement these two mechanisms. We begin with residual claims.

\section{Franchise contract terms supporting franchisees' residual claimant status}

\footnotetext{
${ }^{14}$ Consistent with this, Kaufmann and Lafontaine (1994) present evidence that franchisors monitor the behavior of their store managers much more often than that of franchisees. Further, Bradach (1997) finds that the franchisors he studies use elaborate supervision and monitoring schemes for their store managers, but that they shun the use of the same mechanisms for their franchisees.
} 
Contract terms defining the financial obligations of franchisees, along with contract terms that allow franchisors to ensure franchisee performance of these obligations, and finally franchisee prerogative to transfer ownership of a franchise all contribute to establish residual claimancy rights within franchise contracts. The financial terms define the apportionment of residual claims among parties to the franchise contract; the franchisor's access to specific type of information ensures that the defined apportionment of residual claims is correctly effected; and the franchisees' prerogative to transfer ownership of a franchise ensures that franchisees can appropriate the current and future profits due to their effort and investments.

As mentioned in Section 3, residual claimancy incentives would be fully implemented if franchisees purchased their businesses for a fixed fee only. However, the optimal (second-best) linear contract involves sharing when the franchisee is risk averse or when there is a need to give incentives to the franchisor as well as the franchisee. In that context, the financial terms that implement residual claims in franchise contracts include not only the up-front franchise fee, but also most notably the royalty rate and advertising fee, both of which are normally defined as a proportion of revenues, and clauses specifying input purchase requirements when these inputs are sold at a markup. ${ }^{15}$

To the financial terms of the contract, one must add contract terms that allow the franchisor to obtain accurate accounting and sales information to calculate royalties and advertising fees. Specifically, one usually finds clauses defining precisely the store revenue that is subject to royalty payments and advertising fees. Other clauses indicate the method and frequency with which the relevant revenue data must be transmitted to the franchisor. Still other

\footnotetext{
${ }^{15}$ In some business-format franchises, the royalty rate or advertising fee is replaced by an ongoing fixed payment. Abstracting from issues of termination or failure, these are equivalent to an upfront fixed fee from an incentive perspective.
} 
clauses stipulate the circumstances under which the franchisor will be able to conduct his own store audits and other forms of financial verification to ensure the validity of the information he receives.

Finally, contract terms that accord franchisees the right to transfer their franchise to someone else serve an important role in implementing residual claim as well as self-enforcement incentives. Franchisees usually own or finance much of the franchise's assets (which may, or may not include the actual building within which the franchise is housed), and can sell their franchise (subject to approval of the buyer by the franchisor). ${ }^{16}$ The ownership of the franchise, and its inherent transferability through sale, makes the franchisor's promise of future residual claims (and related future rent) credible (Lutz, 1995). As such, they give franchisees' incentives to invest resources and effort in future as well as current revenues and returns.

\section{Franchise contract terms supporting the self-enforcement mechanism}

As explained earlier, self-enforcement incentives require that contracting parties always be better off by continuing to operate within the contract than by risking discontinuation. Contract terms can implement this condition by increasing the expected gains from continuation $\left(W_{t}^{2}\right)$ and/or decreasing the expected gains from deviation $\left(W_{t}^{l}\right)$. The former involves increasing expected ongoing rent through favorable financial terms as well as, potentially, entry restrictions, lengthy contract duration, a high likelihood of renewal and a policy of allowing or fostering multi-unit ownership among franchisees. The latter involves restricting franchisee conduct through terms stipulating, for example, specific operating procedures, acceptable input sources, minimum advertising expenditure levels, or suggested pricing levels.

\footnotetext{
${ }^{16}$ Franchisors may also have a right of first refusal.
} 


\section{A. Increasing expected rent $\left(W_{t}^{2}\right)$}

The financial terms of the contract described above determine the apportionment of revenues between franchisor and franchisee, and the amount of rent left downstream with the franchisee. In fact, as noted in section 3, once the optimal sharing parameter (sum of royalty rate and advertising fee) is determined, there is a maximum fixed fee that the franchisor can charge for the franchise. This maximum fixed fee is equal to the present value of the expected returns (ex post rent) of the franchise over the duration of the contract, given the chosen share parameter. If the franchisor sets the franchise fee at this level, there is no expected rent ex ante from owning the franchise. There is, however, ex-post rent downstream which may suffice to ensure franchisee performance. If the franchise fee is set at a lower level than this maximum, there is both ex ante and ex post rent left downstream in the franchised chain. The level of ex ante rent earned by the franchisee in fact is exactly equal to the difference between the present value of the stream of ex post rent expected over the duration of the contract and the initial fee. Thus holding the franchise fee fixed, factors that increase expected rent ex post also lead to higher expected ex ante rent.

Restricting new entry into the franchised chain ensures a degree of ongoing market power for individual franchisees. In concert with the allocation of exclusive territories ${ }^{17}$, such entry restrictions limit intra-brand competition and thus increase the amount of ex post rent for franchisees. After setting the financial terms of the contract, it is therefore through the number of franchises sold in each market that the franchisor most directly affects the level of revenues

\footnotetext{
${ }^{17}$ Various surveys indicate that in the US, about two out of every three franchisors offer exclusive territories to their franchisees. Furthermore, "master franchises" agreements all involve some form of territory. Master franchise agreements take one of two main forms: area development agreements, where the selected franchisee normally develops and owns all the outlets on his territory, and sub-franchising agreements, where the "master franchisee" is expected to recruit and support (i.e. play the role of franchisor for) franchisees he establishes on his territory.
} 
and rent for franchisees. Moreover, these decisions determine the density of outlets and thus the level of all forms of externality across outlets in the market. ${ }^{18}$

By using stringent criteria to qualify prospective franchisees, the franchisor also helps ensure that chain homogeneity and quality, and thus franchisee rent, are maintained over the long run. The franchisor seeks motivated individuals with the demonstrated ability to manage the day-to-day operations of an outlet while respecting the franchise chain's restrictions and its rules. Furthermore, to acquire a particular franchise, a prospective franchisee must satisfy certain franchisor requirements, often including a minimum net worth and/or some level of prior business experience. During the training period the franchisor and the franchisee also each gain important information about "fit." The franchisor can assess the strengths and weaknesses of each potential franchisee while franchisees can determine whether the business activity and franchisee role are right for them. A thorough selection process and strong training program screens out prospective franchisees whose lack of motivation or ability could erode brand value, thereby providing current franchisees a measure of security against dissipation of their expected rent.

The length of the franchise contract also affects the amount of rent franchisees can expect to earn within the franchise relationship. The average length of franchise contracts in the US is about 15 years according to the US Department of Commerce, with most of them lasting from 5 to 25 years. The main advantage of longer-term contracts is that the franchisee can count on appropriating the returns to his long-term investments and is therefore more apt to make such

\footnotetext{
${ }^{18}$ Also, by granting franchisees several outlets that are close to one another, the franchisor may benefit even more as the franchisee then internalizes more of the horizontal effects of his behavior, and free rides less. Kalnins and Lafontaine (2001) find evidence that franchisors do allocate outlets in ways that create franchisee-owned clusters. Also, Brickley (1999) finds that area development agreements - contracts through which franchisees are initially given the right to open several outlets - are significantly more likely to be used by franchisors involved in nonrepeat customer industries, where free-riding is especially an issue.
} 
investments. In addition, all else equal, long-term contracts directly imply higher levels of future rent $\left(W_{t}^{2}\right)$ at least early on in the relationship. On the other hand, long-term contracts may increase the cost of self-enforcement by making it more difficult to "end" the relationship itself via non-renewal or termination. Courts may be more reluctant to endorse early termination of long-term contracts, or they may require that franchisors compensate franchisees more when they terminate such a contract, which would negate the incentive or self-enforcement nature of the contract. By contrast, a shorter-term contract makes it less costly for a franchisor to wait until contract expiration and simply refuse to renew. In this case, the use of short-term contracts would enable franchisors to avoid termination and its associated costs altogether. ${ }^{19}$ In sum, decisions regarding contract duration must balance the need for franchisee investment and the costs of enforcement.

Finally, the probability of contract renewal and the availability of additional outlets within the chain play very similar roles as contract duration in the motivation of franchisees. Specifically, renewal implies that the franchisee can expect his stream of ex post rent to continue beyond contract expiration. The higher the probability of this event, the higher is the amount of rent associated with maintaining the relationship. ${ }^{20}$ As for additional outlets, they can also serve to extend the period of expected rent ex post beyond the expiration of the first contract. ${ }^{21}$ However, they can be even more valuable as an incentive mechanism if franchisees can expect to earn rent ex ante from these (i.e. if the franchise fee or purchase price for additional outlets is

\footnotetext{
${ }^{19}$ Legal rules against termination imposed in some US states apply also to non-renewals, but the latter remain easier and less costly to implement.

${ }^{20}$ Franchisors often request the payment of a new fixed fee upon renewal. This fixed fee should be deducted from expected ex-post rent over the renewal period, and the result multiplied by the probability of renewal, to get an estimate of the ex-ante expected amount of rent from renewal.

${ }^{21}$ In fact, if the probability of renewal is very low, and the likelihood of additional outlets almost nil, the expected rent of the franchisee, and thus his incentives not to free ride or damage the brand, will diminish gradually over the duration of the contract.
} 
below the present value of expected returns from these generally, or for this particular franchisee because he already owns other units in the same market and will benefit from additional market power or efficiencies with the new unit). ${ }^{22}$

\section{B. Restricting the gains from deviation $\left(W_{t}^{1}\right)$}

Most franchise contracts include terms stipulating that the franchisee must operate his or her outlet according to the norms set by the franchisor in the operations manuals. In fact, these manuals and the detailed instructions they provide are often included in the contract by reference. ${ }^{23}$ Moreover, the contract usually includes a clause indicating that the franchisor can modify these manuals as needed. The franchisor therefore can impose a large set of detailed rules on the franchisee's operations, and has the option of changing these rules in mid stream. From an incentive perspective, these rules provide an evolving series of fairly objective criteria that can be used to justify and facilitate contract termination. They also limit the franchisee's opportunities to free ride and thus the profits he can obtain from free-riding generally.

Other specific contract clauses limit the franchisees' options and thus increase franchisor control. These include input purchase requirements or approved supplier clauses ${ }^{24}$, minimum advertising expense requirements, and suggested prices. ${ }^{25}$ Non-compliance with such

\footnotetext{
${ }^{22}$ See Kalnins and Lafontaine (2001) for further discussion of the potential benefits franchisees can derive from owning multiple units in a market, and for evidence that large fast-food franchisors allocate new units to franchisees such that each multi-unit franchisee tends to own a cluster of neighboring units.

${ }^{23}$ Operations manuals are usually very detailed, to the point of including, for example, pictures of what plates should look like when served in a restaurant chain, including the position of each item on the plate.

${ }^{24}$ Siegel et al. V. Chicken Delight, Inc, 448 F. 2 d43 ( $9^{\text {th }}$ Circuit, 1971) established that input purchase requirements were a form of tying for business format franchisors as long as the inputs were a separate product from the brand. As a result, business format franchisors in the US rely on approved suppliers rather than input purchase requirements to control input quality. See Klein and Saft (1985) and Blair and Herndon (1999) for more on the issue of tying in franchise contracting and its antitrust treatment in the US.

${ }^{25}$ Resale price maintenance is per se illegal under US antitrust laws. However, a 1997 Supreme Court decision has made maximum resale prices for all intents and purposes legal. See Blair and Lafontaine (1999) for more on this.
} 
restrictions is easily verified by the court system. In that sense, their use reduces franchisees' opportunities to maximize their profits at the expense of the overall system.

Finally, if all these clauses and control mechanisms prove insufficient to induce the desired behavior from franchisees, or are simply too costly to implement, the franchisor can choose to vertically integrate any particular outlet. In that case, since managers are not typically paid based on profits or revenues (and do not have a stake in future profits or revenues either), the franchisor loses the incentive effects associated with residual claims. However, an efficiency wage can be put in place, and the store manager can be further motivated by the hope of promotion, in the form of a transfer to an outlet in a more desirable location, or to higher levels of the franchisor's corporate hierarchy. In fact, most franchisors own and operate a number of outlets in their system. ${ }^{26}$ In that sense, the option of vertically integrating outlets is a very viable one.

In sum, franchisors use a number of contract clauses and incentive mechanisms that allow the franchise system to benefit from the effort and dedication of the individual franchisee/owner while limiting his or her ability to impose negative externalities on other franchisees or the franchised chain. Many of these clauses simultaneously support both types of incentive mechanisms used in franchise contracting. For example, financial contract terms simultaneously apportion residual claims and determine the amount of rent in the relationship. Similarly, sporadic audits are necessary to ensure that the revenues are declared and shared according to the

\footnotetext{
${ }^{26}$ On average, US franchisors operate about $20 \%$ of all their units, despite about $25 \%$ of franchisors operating none. Similarly, in France, about $78 \%$ of all franchised systems include both franchised and corporate units. See e.g. Lafontaine (1992) and Lafontaine and Shaw (2001) for evidence from the US, Allam and Le Gall (1999) and Pénard, Raynaud and Saussier (2002) for evidence from France. Franchisors in Brazil operate an even greater proportion of their units directly according to Azevedo and dos Santos Silva (2001). One finds a number of theories in the literature as to why franchisors might want to combine company owned and franchised outlets within a given chain. It is beyond the scope of the present paper to review this fairly extensive literature, but see Lafontaine and Slade (2001) for a review of the empirical literature on this topic.
} 
terms of the contract, and termination, an essential component of the self-enforcement mechanism, is also the ultimate penalty imposed on a franchisee who does not fully disclose revenues. In fact, it should be clear from the discussion above that the terms of franchise contracts generally complement one another not only in their support of the two incentive mechanisms discussed herein, but, fundamentally, in supporting the franchise system as a whole.

\section{NON-Franchised Systems With COMMON MARK OR REPUTATION CONCERNS}

So far we have discussed how self-enforcement (and the many contract clauses that support it) work together with residual claims to give franchisees the right set of incentives. Fundamentally, we have argued that the franchised system relies on rent to prevent the profit maximizing franchisee from "hurting" the brand in his quest for higher profits. But the need to "protect the brand" or the system is not unique to franchising. In this section, we illustrate via two examples how our analysis also applies to non-franchised systems with a common mark or common reputation concerns.

"Labels rouges" (literally red labels) are used in France to certify the high quality of various agricultural products. These "labels rouges" are government-endorsed marks that groups of producers can collectively create and work under. The creation of such a label requires that all producers in a vertical chain be involved, and that these producers collectively define a set of rules and specifications, codified in the "cahier des charges," under which they promise to operate (see Menard, 1996, and Westgren, 1999, for a description of the organization of production under "labels rouges" in the poultry industry). Different groups of producers within the same agricultural sector can create different "labels rouges" with different rules and specifications. However, all of these must satisfy some minimum requirements to be approved 
as "label rouges." From the consumer's perspective, the different "label rouges" can be distinguished because they each have their own individual identity. For example, in the French poultry industry, there are now more than 80 different "label rouges" $"$.

When they create a "label rouge," producers must also organize and form a "Groupement qualité", which owns the collective mark and is responsible for the enforcement of the rules. This "Groupement qualité" is fundamentally an association of producers, and all producers must enter into a contract with this association before it can sell under this mark.

As each member of a "label rouge" is an independent and separate business, the producers are all full residual claimants when it comes to the proceeds of their individual businesses. Consequently, they may free ride on the common mark or simply maximize their own profits without necessarily taking into account the effect of their behavior on others in the group. Thus the group must institute incentive and control mechanisms. And indeed, many of the clauses found in producer contracts with the "Groupement Qualité" are best understood as ways to make the contracts self-enforcing. In particular, the "Groupement Qualité" has the right to regularly inspect and monitor the behavior of individual producers, and the option to terminate the membership of any producer whose production does not satisfy the rules and specifications set forth in the "Cahier des Charges." Moreover, group members earn rent - they can sell their product at a premium because the label effectively differentiates it and identifies it as a highquality product, and this price premium is protected by territorial exclusivity clauses (e.g. territorial exclusivity for slaughterhouses within a given label) (see Raynaud and Valceschini, 1999 for details).

\footnotetext{
${ }^{27}$ For instance, "poulets de Loué" and "volailles de Challans" where Loué and Challans are different geographical regions.
} 
In sum, the contractual structure of a "label rouge," and in fact of production cooperatives more generally, tends to be very similar to that of a franchised system. Within these systems, individual producers are residual claimants as franchisees are. But the system also includes a central entity that contracts with all producers, like the franchisor does. This central entity also monitors individual producer behavior to make sure they abide by the rules. Finally, like a franchisor, the central entity must be able to exclude producers that do not abide by the rules and, as a result, cause them to lose access to a stream of rent.

In a similar vein, Arrunada (1996) shows the similarities between franchising and the way in which "Civil Law" notaries are organized as a profession in Spain. He notes that under Civil Law, notaries provide private contracting services for which their customers pay them directly. However, these notaries also provide a public good in that they keep records and perform research to ensure the validity of various contracts. The effort they put in these validation activities affects the quality of contracts in the economy, and thus entails significant externalities. The notary, as a residual claimant, would maximize his or her revenues by focusing effort on the production of the private good only. But without any validation activities, the whole civil notaries system breaks down - the reputation of the whole system depends on each notary doing a thorough job of validating and record keeping. Arrunada (1996) argues that rent, due to entry restrictions and price controls for notarized services, and the potential loss of this rent, complement the incentives associated with residual claimancy and ensure the provision of the public as well as the private goods.

\section{Conclusion}

The two types of incentive mechanisms found in franchise contracting are those related to the franchisee's status as a residual claimant, as captured in the principal-agent literature, and 
those related to self-enforcement. The latter focuses on giving franchisees something to lose if the relationship is ended, and combining that with some regular monitoring and termination rights so that the franchisee will indeed have to worry about this potential loss if he does not behave as requested. The literature has generally treated these mechanisms as separate and even substitute incentive mechanisms. Yet empirically they coexist. We have explained this coexistence based on the notion of complementarities. Specifically, we have argued that residual claims give strong incentives to maximize profits, sometimes at the expense of the brand and other group members. The combination of rent and termination rights in that context are tools that the franchisor can use to curb this profit maximization motive when it is hurtful to the overall franchised system. Similarly, relying solely on rent and termination rights would leave the franchisor vulnerable to shirking by franchisees on the day-to-day operations as it would be very costly for the franchisor to do the type of monitoring necessary to prevent this type of misbehavior. Since outlet revenues provide a good measure of franchisee effort for these types of activities, residual claims are the more appropriate incentive tool for these.

Our argument that self-enforcement and residual claims go hand in hand in franchising fits particularly well with Holmstrom and Milgrom's (1994) work on the role of complementarities in the design and workings of incentive systems and with Corts' (2000) argument that agent asset ownership and incentive compensation are complementary when they reward different tasks (while they are substitute when they reward the same tasks). ${ }^{28}$

Though we have focused much of the paper on a particular institutional setting, namely that of the franchise relationship, the points raised here apply in many other settings where

\footnotetext{
${ }^{28}$ See also Athey and Stern (1998) on this. Ichniwoski, Shaw and Prennushi (1997), Cockburn, Henderson and Stern (2001) provide evidence of complementarities in incentive mechanisms in steel production and the pharmaceutical lab context respectively. Finally, Brickley (1999) considers complementarities between a few specific contract clauses in franchising.
} 
legally autonomous businesses or otherwise owners of residual claims share a common brand or reputation concern. Aside from production cooperatives and the system of public notaries described above, one can think, for example, of firms involved in direct sales, of cartel enforcement, and of labor negotiations with common unions as other settings where the need to give incentives to individual members conflicts with the needs of the group and hence the value of group membership. Detailed work into the specifics of how these groups organize their joint activities would be most useful in clarifying further the role of complementarities in contracting, and cross-firm as well as internal organizational issues more generally. 


\section{REFERENCES}

Akerlof, George A. and Janet L. Yellen, (1986), Efficiency Wage Models of the Labor Market, Cambridge University Press.

Allam, D. and P. Le Gall, (1999), La nature de la relation franchiseur-franchisé. Evolution, perspectives et incidences stratégiques, économiques, et juridiques, research report, Université Paris I, Panthéon-Sorbonne.

Arrunada, B. (1996), "The Economics of Notaries", European Journal of Law and Economics, 3 , $5-37$.

Athey, S. and S. Stern (1998), "An Empirical Framework for Testing Theories about Complementarity in Organizational Design", NBER Working Paper 6600.

Azevedo, P. F. and dos Santos Silva, V. L. (2001), "Contractual Mix Analysis in Brazilian Franchising," mimeo, Federal University of São Carlos, SP, Brazil.

Barron, J.M. and J.R. Umbeck (1984), "The Effects of Different Contractual Arrangements: The Case of Retail Gasoline," Journal of Law and Economics, XXVII, 313-328.

Beales, H. and Muris, T.J. (1995), "The Foundation of Franchise Regulation: Issues and Evidence", Journal of Corporate Finance: Contracting, Governance and Organization, 2, 157-197.

Bhattacharyya, S. and Lafontaine, F. (1995), "Double-sided Moral Hazard and the Nature of Share Contracts", RAND Journal of Economics, 26, 761-781.

Blair, R.D. and Kaserman, D. L. (1994), "A Note on Incentive Incompatibility under Franchising," Review of Industrial Organization, 9, 323-330.

Blair and Herndon, (1999) "The Misapplication of Kodak in Franchise Tying Suits," Journal of Business Venturing, 14, 397-415.

Blair, R.D. and Lafontaine, F. (1999), "Will Khan Foster or Hinder Franchising? An Economic Analysis of Maximum Resale Price Maintenance," Journal of Public Policy in Marketing, 18, 25-36.

Bradach, J.L. (1997), "Using the Plural Form in the Management of Restaurant Chains," Administrative Science Quarterly, 42, 276-303.

Brickley, James A. (1999), "Incentive Conflicts and Contracting: Evidence from Franchising", Journal of Law and Economics, XXXXII, 745-774

Brickley, J.A. (2001) "Evidence of Life-Cycle Pricing in Franchise Contracts" mimeo, Simon School of Business, University of Rochester.

Brickley, J.A. (2002) "Royalty Rates and Franchise Fees in Share Contracts: Evidence from Franchising" mimeo, Simon School of Business, University of Rochester.

Brickley, J.A. and Dark, F.H. (1987), "The Choice of Organizational Form: The Case of Franchising", Journal of Financial Economics, 18, 401-420.

Brickley, J.A., Dark, F.H. and Weisbach, M.S. (1991), "The Economic Effect of Franchise Termination Laws", Journal of Law and Economics, XXXIV, 101-132.

Cockburn, I., R. Henderson, and S. Stern, (2000), "Balancing Incentives: The Tension Between Basic and Applied Research," mimeo, MIT Sloan School. 
Corts, K. (2000) "The Interaction of Task and Asset Allocation in Multi-task Agency Relationships," Harvard Business School, Working Paper \# 01-049.

Eswaran, M. and A. Kotwal (1985), "A Theory of Contractual Structure in Agriculture," American Economic Review, 75, 352-367.

Holmstrom, B. and Milgrom, P. (1994), "The Firm as an Incentive System", American Economic Review, 84, 972-991.

Ichniowski, C., K.L Shaw and G. Prennushi (1997), "The Effects of Human Resource Management Practices on Productivity: Evidence from the Steel Industry", American Economic Review, 87, 291-313.

Kalnins, A. and Lafontaine, F. (2001), "Multi-Unit Ownership in Franchising: Evidence from the Texan Fast-Food Industry", mimeo, University of Michigan Business School.

Kaufmann, P. J. (1987), "Pizza Hut,” Harvard Business School Case.

Kaufmann, P. and Lafontaine, F. (1994), "Costs of Control; The Source of Economic Rents for McDonald's Franchisees", Journal of Law and Economics, XXXVII, 417-453.

Klein, B. (1980), "Transaction Costs Determinants of Unfair Contractual Arrangements", American Economic Review, 70, 356-362.

Klein, B. (1995), "The Economics of Franchise Contracts", Journal of Corporate Finance: Contracting, Governance and Organization, 2, 9-37.

Klein, B. and Leffler, K. (1981), "The Role of Market Forces in Assuring Contractual Performance", Journal of Political Economy, 89, 615-641.

Klein, B. and Saft, L. (1985), "The Law and Economics of Franchise Tying Contracts", Journal of Law and Economics, XXVIII, 345-361.

Lafontaine, F. (1992), "Agency Theory and Franchising; Some Empirical Results", RAND Journal of Economics, 23, 263-283.

Lafontaine F. and S. Bhattacharyya, (1995) "The Role of Risk in Franchising," Journal of Corporate Finance: Contracting, Governance, and Organization, 2, pp. 39-74.

Lafontaine, F. (2001), "Retail Pricing, Organizational Form, and the New Rule of Reason Approach to Maximum Resale Prices", mimeo, University of Michigan Business School.

Lafontaine, F. and Shaw, K. (2001), "Targeting Managerial Control: Evidence from Franchising", mimeo, University of Michigan Business School.

Lafontaine, F. and Slade, M. (1996), "Retail Contracting and Costly Monitoring: Theory and Evidence", European Economic Review Papers and Proceedings, 40, 923-932.

Lafontaine, F. and Slade, M. (2001), "Incentive Contracting and the Franchise Decision", K. Chatterjee and W. Samuelson (eds), Advances in Business Application of Game Theory, Kluwer Academic Press.

Lal, R. (1990), "Improving Channel Coordination through Franchising", Marketing Science, 9, 299-318.

Lewin-Solomon, S.B. (1998), "The Plural Form in Franchising: A Synergism of Market and Hierarchy", Working Paper, Dept. of Economics, Iowa State University.

Lutz, N.A. (1995), "Ownership Rights and Incentives in Franchising”, Journal of Corporate Finance : Contracting, Governance and Organization, 2, 103-130. 
Mathewson, F. and Winter, R. (1985), "The Economics of Franchise Contracts", Journal of Law and Economics, XXVIII, 503-526.

Ménard, C. (1996), "Of Clusters, Hybrids and Other Strange Forms: The Case of the French Poultry Industry”, Journal of Institutional and Theoretical Economics, 152, 154-183.

Michael, S. and Moore, H. (1995), "Returns to Franchising". Journal of Corporate Finance: Contracting, Governance and Organization, 2, 133-155.

Milgrom, P. and J. Roberts, (1992), Economics, Organization \& Management, Englewood Cliffs, NJ: Prentice Hall.

Pénard, T., E. Raynaud and S. Saussier (2002): "Dual Distribution and Royalty Rates in Franchised Chains: An Empirical Exploration using French Data", working paper, Centre ATOM, University of Paris I.

Prendergast, C. "The Tenuous Trade-Off Between Risk and Incentives," Journal of Political Economy, forthcoming.

Raynaud, E. and Valceschini, E. (1999), "Crédibilité d'un signal commun de qualité et structures de gouvernance", mimeo, Centre ATOM, University of Paris I.

Rubin, P. (1978), "The Theory of the Firm and the Structure of Franchise Contracts", Journal of Law and Economics, XXI, 223-232.

Shapiro, C., Stiglitz, J.E. (1984), "Equilibrium Unemployment as a Worker Discipline Device”, American Economic Review, 74, 433-444.

Shelton, J., (1967), "Allocative Efficiency vs. "X-Efficiency": Comment", American Economic Review, December, 1252-1258.

Shepard, A. (1993), "Contractual Form, Retail Price, and Asset Characteristics," RAND Journal of Economics, 24, 58-77.

Stiglitz, J. E. (1974), "Incentives and Risk Sharing in Sharecropping”, Review of Economic Studies, 41, 397-426.

Westgren, R.E. (1999), "Delivering Food Safety, Food Quality, and Sustainable Production Practices: The Label Rouge Poultry System in France", American Journal of Agricultural Economics, 81, n. 5, 1107-1111.

Williams, D.L. (1996) "Incomplete Contracting and Ex-Post Opportunism: Evidence from Franchise Contract Terminations," mimeo, UCLA, Dept. of Economics.

Williamson, O.E. (1985), The Economic Institutions of Capitalism: Firm, Market and Relational Contracting, New York, The Free Press.

Williamson, O.E. (1991), "Comparative Economic Organization: The Analysis of Discrete Structural Alternatives”, Administrative Science Quarterly, 36, 269-296. 